\title{
The Effectiveness of Modified Free Inquiry Strategies to Enhance Mastery of Molecular Biology Concepts
}

\author{
Evi Suryanti ${ }^{1}$, Any Fitriani ${ }^{2}$, Sri Redjeki ${ }^{3}$, Riandi $^{4}$ \\ \{evisuryanti97@ student.upi.edu ${ }^{1}$, anyfitriani@yahoo.com ${ }^{2}$, sri.redjeki.n@gmail.com ${ }^{3}$ \} \\ Science Education Program, School of Postgraduate Studies, Universitas Pendidikan Indonesia, \\ J1. Dr. Setiabudhi 229 Bandung 40154, Bandung, Indonesia ${ }^{1,2,3,4}$ \\ Biology Education Program, Faculty of Teacher Training and Education, Universitas Islam Riau, \\ Jl. Kaharuddin Nasution 113 Pekanbaru 28284, Riau, Indonesia ${ }^{1}$
}

\begin{abstract}
This study aims to test the effectiveness of the modified free inquiry strategy in molecular biology. The quasi-experimental method used involves one experiment and one control group. Topics covered are DNA Isolation, Electrophoresis, and Polymerase chain reaction (PCR). Multiple choice objective tests have been used as data collection instruments. Statistical differences test shows that no significant difference in mean scores between the two groups on all topics, so it was concluded that modified free inquiry strategy was not effective in molecular biology especially on the topic of DNA Isolation, Electrophoresis, and PCR. The implication of this research is that the use of the modified free inquiry strategies can be supplemented with computer-based technologies such as virtual laboratories, and portfolio instruments can be used as alternative assessments to assess students' mastery of concepts.
\end{abstract}

Keywords: Effectiveness, learning strategy, modified free inquiry, mastery of concepts, molecular biology

\section{Introduction}

Inquiry has been an important goal of science education for decades [1]. The ability of students in inquiry learning is an important component in the reform of science education [2]. Various studies related to inquiry such as the application of inquiry [3] and [1], inquiry curriculum [4], assessment in inquiry [5] are carried out in science learning to meet the demands of Teaching Standards in the National Science Education Standards that require science teachers plan inquiry-based science teaching programs for their students [6]. Inquiry-based teaching is widely promoted to enhance students' conceptual understanding and involvement in material content [4].

In Indonesia, one of the recommended learning models in the Kurikulum 2013 is inquiry. The National Science Education Standards (NSES) define inquiry as multidirectional activities carried out by students such as observing, asking questions, gathering information from various sources, planning and conducting investigations, using evidence to explain questions, using equipment to search, collect and interpret data; propose answers, questions, and predictions; and communicating findings [6]. Based on the opinion of previous researchers there are two types of inquiry, namely: a) Guided inquiry; where the teacher provides students with interesting research questions and guides students to the appropriate experimental design; and b) Open- 
ended inquiry; less structured in which students are asked to ask their own research questions and develop appropriate methods to answer these questions [7]. The characteristics of free inquiry learning are students formulating their own problems, connecting new knowledge with prior knowledge, working collaboratively by sharing and discussing with peers so students are intrinsically motivated to learn [8]. Prospective biology teacher candidates who are trained in inquiry learning are expected to have the inquiry ability as a basis for learning biology or science in primary and secondary schools.

One branch of Biology that is scientifically and technically innovative, rapidly developing, and has broad effects on various aspects of daily life is Molecular Biology. The contents of molecular biology are complex, highly abstract, and are rooted in various disciplines ranging from pure sciences (mathematics, chemistry, and physics) to applied sciences (such as medicine and agriculture) [9]. Other researchers also argue that most concepts and processes in molecular biology are abstract [10]. Related to the nature of the molecular biology content, the study found that there were students who had difficulty in understanding the complexity and interrelationship of processes in molecular biology content [11] and experienced misconceptions on molecular genetic concepts such as DNA, genes, chromosomes, and protein synthesis [12]. In addition, the other research also found that teachers did not teach certain molecular biology techniques in the class because of the lack of confidence [13]. The findings of these studies indicate that learning molecular biology must be improved to achieve more optimal results. With all the advantages possessed by inquiry as a learning strategy and in accordance with curriculum demands, the inquiry strategy is assumed to be able to overcome limitations in learning molecular biology. In addition, based on a meta-analysis literature review it is suggested that inquiry learning in biology can improve student learning outcomes [7]. The type of inquiry used in this study is free inquiry that is modified to suit the allocation of learning time and the limitations of laboratory facilities. Based on the description above, the purpose of this study is to test the effectiveness of the modified free inquiry strategy in enhancing mastery of molecular biology concepts.

\section{Method}

The research design used was a quasi experiment. The research subjects were students of Biology Education Program at a private university in Kota Pekanbaru on Academic Year 2018/2019. The experimental group consisted of 35 students (1 male and 34 female) and the control group consisted of 35 students ( 3 male and 32 female). The topics studied were DNA Isolation, Electrophoresis, and Polymerase chain reaction (PCR). The steps of the modified free inquiry strategy are: orienting students to problems, students formulating problems and propose hypotheses, collecting data and information to test hypotheses, communicating findings, and concluding.

The research instrument was a concept mastery test in the form of multiple choice objective questions totaling 66 items with 26 items for DNA Isolation, 19 items for Electrophoresis, and 21 items for PCR. Validation analysis includes logical and empirical validation. Logical validation involved expert lecturers in Biology Education, Biology, and Biochemistry. Empirical validation was conducted by testing the test on 41 students of Biology Education Program at the same institution in the Academic Year 2017/2018. Test scores from the test instruments are analyzed to determine the validity and reliability of the test instruments. 
Empirical validity analysis is performed by calculating the correlation coefficient $\left(\mathrm{r}_{\mathrm{xy}}\right)$. The criterion for validity is if $r_{x y}<r_{\text {table }}$, the items are invalid, whereas if $r_{x y} \geq r_{\text {table }}$, the items are valid. The results of the analysis of the test scores obtained data that 30 items $(45.45 \%)$ are valid and the remaining 36 items $(54.55 \%)$ are invalid with $r_{\text {table }}=0.308$ at the significance level $\alpha=5 \%$. Reliability analysis was performed by calculating the Cronbach's alpha coefficient (r). Criteria for reliability are: $>0.90$ (very highly reliable), 0.80-0.90 (highly reliable), 0.70-0.79 (reliable), 0.60-0.69 (marginally/minimally reliable), and < 0.60 (unacceptably low reliability) [14]. The analysis results obtained the Chronbach's alpha coefficient is 0.792 (reliable). Determination of effectiveness is based on statistical analysis of the Mann-Whitney $U$ test or Independent samples t-test on the mean scores of the concept mastery test in both classes of research. The effectiveness criterion is: if there is a significant difference $=$ 'effective', and if there is no significant difference $=$ 'ineffective'.

\section{Result and Discussion}

This section presents the result of data analysis followed by a discussion of these results in relation to the theory or findings of previous research

\subsection{The validity and reliability of concept mastery tests}

Logical validity includes content and constructs validity. Starting from the beginning of constructing the test instrument has been carefully designed, adapted to the material discussed, referring to the grids of questions, and adjusted to the learning objectives to be achieved, so the completed instrument has fulfilled logical validity. This is supported by the statement [15] that if a test is made that has referred to what is to be measured and is in accordance with theoretical construction, then logical validity has been fulfilled. Logical validity is also called qualitative analysis, namely analyzing questions in terms of content (material), technical (construction), and editorial (language). Suggestions from validators are used to improve test instruments to get better. The results of the empirical validity analysis showed 30 items (45.45\%) were valid and the remaining 36 items $(54.55 \%)$ were invalid with $r_{\text {table }}=0.308$ at the significance level $\alpha=$ $5 \%$. Chronbach's alpha coefficient of 0.792 indicates a reliable concept mastery test. Based on the analysis results, editorial improvements have been made to the test instrument. Due to unnecessary time to replace invalid questions, the revised test instrument is still used for the experiment.

\subsection{Effectiveness of the modified free inquiry strategy}

The achievements of the concept mastery test results in the two research groups are summarized in Table 1:

Table 1. Comparison of acquisition scores of concept mastery.

\begin{tabular}{lllllll}
\hline Component & \multicolumn{2}{l}{ DNA isolation } & \multicolumn{2}{l}{ Electrophoresis } & PCR & \\
\cline { 2 - 7 } & Exp. & Control & Exp. & Control & Exp. & Control \\
\hline Lowest score & 26,92 & 46,15 & 21,05 & 31,58 & 19,05 & 23,81 \\
\hline Highest score & 80,77 & 80,77 & 94,74 & 78,95 & 80,95 & 76,19 \\
\hline Mean score & 58,35 & 61,32 & 50,83 & 54,74 & 54,01 & 52,93 \\
\hline
\end{tabular}




\begin{tabular}{lllllll}
\hline Component & \multicolumn{2}{l}{ DNA isolation } & \multicolumn{2}{l}{ Electrophoresis } & PCR & \\
\cline { 2 - 7 } & Exp. & Control & Exp. & Control & Exp. & Control \\
\hline Standard deviation & 12,07 & 9,09 & 16,04 & 12,84 & 13,81 & 14,27 \\
\hline
\end{tabular}

It appears in Table 1 that the experimental group did not always get better scores than the control group for all components. The experimental group had the lowest score lower than the control group for all topics. The experimental and control group got the same score on the topic of DNA Isolation for the highest score component, while in the other two topics the experimental group got a higher score than the control group. The experimental group obtained lower mean scores than the control group on the topic of DNA Isolation and Electrophoresis, whereas on the PCR topic the experimental group was higher than the control group. The experimental group had a higher standard deviation than the control group on the topic of DNA Isolation and Electrophoresis, whereas on the PCR topic the control group was higher. Based on the data in Table 1 there were inconsistent between the achievement of the experimental and control groups, then the statistical difference test of the mean scores was carried out and a summary of the test results can be seen in Table 2 :

Table 2. The results of statistical difference tests on the mean scores of concept mastery.

\begin{tabular}{|c|c|c|c|c|}
\hline Topic & Group & Mean & $\begin{array}{l}\text { Normality test* } \\
\text { (Kolmogorov- } \\
\text { Smirnov test) }\end{array}$ & Statistical difference tests ${ }^{*}$ \\
\hline \multirow[t]{2}{*}{ DNA Isolation } & Exp. & 58,35 & $\begin{array}{l}\text { Sig. }=0,002 \\
(\text { Not normal) }\end{array}$ & \multirow{2}{*}{$\begin{array}{l}\text { Mann-Whitney } U \text { test } \\
\text { Sig. (2-tailed) } 0,348 \\
\text { (no significant difference) }\end{array}$} \\
\hline & Control & 61,32 & $\begin{array}{l}\text { Sig. }=0,200 \\
\text { (Normal) }\end{array}$ & \\
\hline \multirow[t]{2}{*}{ Electrophoresis } & Exp. & 50,83 & $\begin{array}{l}\text { Sig. }=0,200 \\
(\text { Normal) }\end{array}$ & \multirow{2}{*}{$\begin{array}{l}\text { Independent samples } t \text {-test } \\
\text { Sig. (2-tailed) } 0,264 \\
\text { (no significant difference) }\end{array}$} \\
\hline & Control & 54,74 & $\begin{array}{l}\text { Sig. }=0,135 \\
\text { (Normal) }\end{array}$ & \\
\hline \multirow[t]{2}{*}{ PCR } & Exp. & 54,01 & $\begin{array}{l}\text { Sig. }=0,117 \\
(\text { Normal) }\end{array}$ & \multirow{2}{*}{$\begin{array}{l}\text { Mann-Whitney } U \text { test } \\
\text { Sig. (2-tailed) } 0,868 \\
\text { (no significant difference) }\end{array}$} \\
\hline & Control & 52,93 & $\begin{array}{l}\text { Sig. }=0,047 \\
(\text { Not normal) }\end{array}$ & \\
\hline
\end{tabular}

It can be seen in Table 2 that the results of the statistical difference tests are there is no significant difference in mean scores between the two groups on all topics. This indicates that there is no effect of the application of the modified free inquiry strategy to mastering the concept of molecular biology, meaning that the modified free inquiry strategy is not effective in enhancing concepts mastery of molecular biology especially on the topic of DNA Isolation, Electrophoresis, and PCR. This finding contradicts with the results of previous studies on different topics where the method of free inquiry with its various modifications affects the improvement of psychomotor learning outcomes in static fluid topic [16]; aspect of knowledge [17\}; the knowledge, attitudes and skills [18]; student creativity and acquisition of learning outcomes in chemical analysis topic [19]; student achievement in the heat topic [20]; reduce the number of students who are misconceptions and increase understanding of student concepts in the fluid topic [21]; better learning achievement in the learning process of the circulatory system topic [22] and [23]. Other researcher concluded that the modified free inquiry approach in 
learning causes the psychomotor abilities of students such as making planning, implementing activities and making reports better; the types of experiments that are developed become more and more creative in developing the objectives of the experiment; as well as the creativity and ability of students in understanding wave topic significantly increased [24]. The results of these studies indicate that the modified free inquiry strategy contributes positively to the enhancement of student learning processes and outcomes.

However, in other studies found difficulties faced by students in following inquiry learning in addition to free inquiry, such as the study by [25] found obstacles faced by high school students in the bounded inquiry lab learning model on the concept of diffraction of light by the grids, namely difficulty in answering variable questions, difficulties in determining tools and materials for experiments, difficulties in determining experimental design, difficulties in making graphics, and difficulties in formulating concepts systematically. In addition, the other studies have found that middle school students who had difficulty understanding the material, linking relationships between concepts, understanding formulas, and operating formulas to solve questions in guided inquiry learning on the subject of light [26]. Difficulties faced by students in free inquiry strategies and their modifications may be even more severe because these strategies require students to be more independent in managing their learning and require a higher level of thinking. Another opinion state that free or open inquiry is less structured in which students ask research questions and develop appropriate methods to answer these questions, meaning that the focus of this strategy is on students who must be able to control the learning process independently facilitated by educators [7]. Free inquiry is suitable for talented or proficient students and more appropriate to conduct it outside regular class time [27]. The statement can be interpreted that the application of the free inquiry strategy requires a lot of time and should be applied to classes with students who have average cognitive abilities and above.

The ineffectiveness of modified free inquiry strategies such as inquiry learning might also be caused by teachers. The study found that the difficulty in applying the inquiry teaching approach was that there was substantial variation in the meaning of inquiry teaching among educators, and a lack of understanding of the skills needed to help students generate their own questions [5]. In line with that opinion, another findings stated that the lack of professional development experience of educators as well as a lack of understanding of what actually inquiry teaching can be an inhibiting factor in the application of inquiry [28]. Harris and Rook in [29] explained that there are five interconnected areas that need to be addressed in K-8 inquiry science classes, namely students, assignments, teaching materials, science ideas, and class communities. Based on some of the findings and opinions of these researchers, it can be stated that educators are determinants of the direction of the implementation of inquiry learning, for this task, educators must have knowledge and understand the meaning of inquiry, have experience of selfing, and be actively involved in the community of educators in order to develop their professionalism. The result of the other study also state that teachers experience extreme time restrictions so that they become obstacles in the application of inquiry [28].

Related to the ineffectiveness of the modified free inquiry strategy can also be caused by the test instruments used to measure the mastery of concepts that have not been adequate because of their low validity and reliability at the 'reliable' level. According to [30] mastery of concepts should be assessed individually, not classical and portfolio is an assessment tool that can assess the level of mastery of individual student concepts. However, in most learning in the classroom tests are often used to assess students' mastery of concepts, termed the 'concept mastery test'. Dickson's opinion can also be accepted because Biology is part of the field of science that demands learning competence in the realm of high-level understanding. Understanding is the basic capital for further mastery. Mastery of concepts is a higher stage than 
understanding the concept. To assess the level of understanding, it might be possible to use a test instrument, but for mastery concepts, it should be used as an instrument that can assess individual student performance as a form of its mastery of a concept.

Furthermore, [31] argues that technology can be used to improve inquiry teaching methods. In his study, [32] found that students could generate questions after they interacted online through virtual laboratories and virtual lecture sessions. Learning experience with virtual technology gives students knowledge about science, scientific methods, and also the opportunity to ask questions related to science. The results of the investigation [33] found that students' ability to ask questions could be improved by the availability of authentic science resources in inquiry learning. Based on the research findings, it can be suggested to teachers to be able to develop learning resources based on information and communication technology that can support the implementation of the modified free inquiry strategy, especially in molecular biology.

\section{Conclusion}

The results of the statistical difference tests are there is no significant difference in mean scores between the two groups on all topics. This indicates that there is no effect of the application of the modified free inquiry strategy to mastering the concept of molecular biology, it means that the modified free inquiry strategy is not effective in enhancing concepts mastery of molecular biology especially on the topic of DNA Isolation, Electrophoresis, and PCR. Suggestions that can be recommended for the use of modified free inquiry strategies can be supplemented with computer-based technologies such as virtual laboratories, and portfolio instruments can be used as alternative assessments to assess students' mastery of concepts.

\section{References}

[1] Quigley, C., Marshall, J.C., Deaton, C.C.M., Cook, M.P. and Padilla, M.: Challenges to inquiry teaching and suggestions for how to meet them. Science Educator, 20(1), pp. 55-61 (2011)

[2] Wu, P-H., Wu, H-K. and Hsu, Y-S.: Establishing the criterion-related, construct, and content validities of a simulation-based assessment of inquiry abilities. International Journal of Science Education, 36(10), 1630-1650. doi: 10.1080/09500693.2013.871660 (2014)

[3] van Uum, M.S.J., Verhoeff, R.P. and Peeter, M.: Inquiry-based science education: Towards a pedagogical framework for primary school teachers. International Journal of Science Education, 38(3), 450-469. doi: 10.1080/09500693.2016.1147660 (2016)

[4] Gormally, C., Brickman, P., Hallar, B. and Armstrong, N.: Lessons learned about implementing an inquiry-based curriculum in a college biology laboratory classroom. Journal of College Science Teaching, 40(3), pp. 45-51 (2011)

[5] Bhagat, A.: Inquiry-based learning: Assessing students' science inquiry skills. Teacher, 11(4), pp. 34-37 (2017)

[6] National Research Council.: National Science Education Standards. Washington, DC: National Academy Press (1996)

[7] Beck, C., Butler, A. and da Silva, K.B.: Promoting inquiry-based teaching in laboratory courses: Are we meeting the grade? CBE—Life Sciences Education, 13, pp. 444-452 (2014)

[8] Roth, W.M.: Authentic school science: Knowing and learning in open-inquiry science laboratories (ebook). Netherland: Kluwer Academic Publishers. 10.1007/978-94-011-0495-1 (1995) 
[9] Tibell, L.A.E. and Rundgren, C-J.: Educational challenges of molecular life science: Characteristics and implications for education and research. CBE-Life Sciences Education, 9, pp. 25-33 (2010)

[10] Rotbain, Y., Marbach-Ad, G. and Stavy, R.: Using a computer animation to teach high school molecular biology. J Sci Educ Technol, 17, pp. 49-58. doi: 10.1007/s10956-007- 9080-4 (2008)

[11] McClean, P., Johnson, C., Rogers, R., Daniels, L., Reber, J., Slator, B. M., Terpstra, J. and White, A.: Molecular and cellular biology animations: Development and impact on student learning. Cell Biology Education, 4, pp. 169-179 (2005)

[12] Nurlaila, L., Sriyati, S. and Riandi.: Analizing student biology education misconception and scientific argumentation ability using diagnostic question clusters (DQC) of molecular genetic concept. IOP Conf. Series: Journal of Physics: Conf. Series, 812, 012112. doi:10.1088/1742-6596/812/1/012112 (2017)

[13] Boulay, R., Parisky, A. and Campbell, C.: Developing teachers' understanding of molecular biology: Building a foundation for students. ASCILITE Annu. Conf.: pp. 119-128 (2010)

[14] Cohen, L., Manion, L. and Morrison, K.: Research methods in education. (ebook). 6th edition. Taylor \& Francis e-Library (2007)

[15] Surapranata, S.: Analisis validitas, reliabilitas dan interpretasi hasil tes: Implementasi Kurikulum 2013. Cet. 4. Bandung: Remaja Rosdakarya (2009)

[16] Hadiati, S. and Pramuda, A.: Pembelajaran fisika berorientasi pendidikan karakter dengan metode inkuiri terbimbing dan inkuiri bebas termodifikasi pada materi Fluida Statis. Jurnal Edukasi Matematika dan Sains, 1(1), pp. 28-30 (2016)

[17] Sutopo, Masykuri, M. and Cari.: Pembelajaran fisika dengan model inkuiri terbimbing dan inkuiri bebas termodifikasi ditinjau dari kreativitas dan sikap ilmiah siswa. JURNAL INKUIRI, 5(1), 122132). http://jurnal.fkip.uns.ac.id/index.php/sains (2016)

[18] Handaka, A., Sukarmin, and Sunarno, W.: Pembelajaran fisika melalui konstruktivisme menggunakan metode inkuiri terbimbing dan inkuiri bebas termodifikasi ditinjau dari motivasi berprestasi dan sikap ilmiah. INKUIRI: Jurnal Pendidikan IPA, 7(2), pp. 190-198. doi. 10.20961/inkuiri.v7i2.22972 (2018)

[19] Purwati, Sunarno, W. and Utomo, S. B.: Pembelajaran analisis kimia menggunakan metode inkuiri terbimbing dan inkuiri bebas termodifikasi untuk meningkatkan hasil belajar ditinjau dari kreativitas. INKUIRI: Jurnal Pendidikan IPA, 7(2), pp. 182-189. doi. 10.20961/inkuiri.v7i2.22970 (2018)

[20] Susilo, A., Sunarno, W. and Sukarmin.: Pembelajaran fisika menggunakan metode inkuiri terbimbing dan inkuiri bebas termodifikasi berdasarkan kompendiumal-qur'an ditinjau dari kedisiplinan belajar dan sikap ilmiah. INKUIRI: Jurnal Pendidikan IPA, 7(2), pp. 160-167. doi. 10.20961/inkuiri.v7i2.22966 (2018)

[21] Shofiyah, N.: Penerapan model pembelajaran modified free inquiry untuk mereduksi miskonsepsi mahasiswa pada materi Fluida. Science Education Journal, 1(1), pp. 19-28. doi: 10.21070/sej.v1i1.836 (2017)

[22] Nurkhamid.: Pengaruh Pembelajaran CTL dengan Inkuiri Bebas Termodifikasi dan Inkuiri Terbimbing terhadap Prestasi Belajar Siswa Ditinjau dari Kreativitas Siswa dan Kemampuan Verbal. (Tesis). Universitas Sebelas Maret, Surakarta (2014)

[23] Kristanti, A. A., Sunarno, W. and Suparmi.: Pembelajaran IPA dengan Inkuiri bebas termodifikasi menggunakan lab riil dan lab virtuil ditinjau dari kemampuan berpikir dan gaya belajar siswa. JURNAL INKUIRI, 1(2), pp. 105-111. http://jurnal.pasca.uns.ac.id (2012)

[24] Khanafiyah, S. and Rusilowati, A.: Penerapan pendekatan modified free inquiry sebagai upaya meningkatkan kreativitas mahasiswa calon guru dalam mengembangkan jenis eksperimen dan pemahaman terhadap materi fisika. Berkala Fisika, 13(2), 7-14 (2010)

[25] Syarkowi, A, and Malinda, S.: Identifikasi kendala siswa dalam proses pembelajaran bounded inquiry lab pada konsep difraksi cahaya. Berkala Ilmiah Pendidikan Fisika, 6(3), pp. 315-324. doi: 10.20527/bipf.v6i3.5058 (2018)

[26] Wijayanti, P.I., Mosik, and Hindarto, N.: Eksplorasi kesulitan belajar siswa pada pokok bahasan cahaya dan upaya peningkatan hasil belajar melalui pembelajaran inkuiri terbimbing. Jurnal Pendidikan Fisika Indonesia, 6, pp. 1-5 (2010) 
[27] Wenning, C.J.: Levels of inquiry: Hierarchies of pedagogical practices and inquiri processes. J. Phys. Tchr. Educ. Online, 2(3): pp. 3-12 (2005)

[28] Fitzgerald, M., Danaia, L. and McKinnon, D.H.: Barriers inhibiting inquiry-based science teaching and potential solutions: Perceptions of positively inclined early adopters. Research in Science Education. doi: 10.1007/s11165-017-9623-5 (2017)

[29] Lister, C.A.P.: A Framework for Implementing Inquiry-Based Learning in the Elementary Classroom. (Tesis). University of Victoria (2015)

[30] Dickson, S.M.: Tracking concept mastery using a biology portfolio. The American Biology Teacher, 66(9), pp. 628-634 (2004)

[31] Theis, J. L.: Technology Predictors of Inquiry-Based Teaching: An Examination of Two K-12 1:1 Pilots. (Disertasi). Bowling Green State University (2016)

[32] Fauville, G.: Questions as indicators of ocean literacy: Students' online asynchronous discussion with a marine scientist. International Journal of Science Education, 39(16), pp. 2151-2170. https://doi.org/10.1080/09500693.2017.1365184 (2017)

[33] Lombard, F.E. and Schneider, D.K.: Good student questions in inquiry learning. Journal of Biological Education, 47(3), pp. 166-174. https://doi.org/10.1080/00219266.2013.821749 (2013) 